\title{
Suitability of an Algal Biofuel Species, Scenedesmus acutus, as a Fertilizer for Growth of Conventional and Genetically Modified Lettuce
}

\author{
Neng-Iong Chan \\ School of Life Sciences, P.O. Box 87461, Arizona State University, \\ Tempe, AZ 85287-4601
}

\author{
Bruce E. Rittmann \\ Biodesign Swette Center for Environmental Biotechnology, Arizona State \\ University, 727 E. Tyler Street, Tempe, AZ 85287-5701
}

\begin{abstract}
James Elser
Flathead Lake Bio Station, University of Montana, 32125 Bio Station Lane, Polson, MT 59860-6815; and School of Sustainability, Arizona State University, 727 E. Tyler Street, Tempe, AZ 85287-6701
\end{abstract}

Additional index words. algae, biomass yield, fertilizer, lettuce, phosphorus

\begin{abstract}
Nitrogen (N) and phosphorus (P) are important elements for global food production, but these nutrients cause pollution in water bodies without proper management. Furthermore, $P$ is a finite resource with geologic reserves that are geographically restricted. Thus, sustainable use of $P$ in agriculture has been the subject of much research over the past decade. This study jointly examines two examples of potential sustainability measures to address nutrient challenges: improved crop varieties and use of recycled fertilizers. We tested the effectiveness of dried biomass of a freshwater alga (Scenedesmus acutus) as a fertilizer with conventional lettuce [Lactuca sativa cv. Conquistador; WT (wild-type)] and genetically modified lettuce of the same variety that was transformed for improved nutrient-use efficiency [(type I Arabidopsis Vacuolar Pyrophosphatase (AVP1)]. In greenhouse conditions, we measured yield, soil nutrient content and losses, and soil $P$ fractions after application of dried $S$. acutus biomass at different rates, with and without supplemental additions of conventional fertilizer. Yield was higher with commercial fertilizer compared with algal fertilizer, and AVP1 lettuce consistently produced better yield than the conventional lettuce with both fertilizer types, although the effect was stronger with the algal treatments. Soil $P$ was mostly sequestered in the pools of NaHCO3-extractable organic $\mathrm{P}, \mathrm{NaOH}$-extractable organic $\mathrm{P}$, and $\mathrm{HCl}$-extractable $P$, which are poorly available. Although the algal fertilizer was ineffective in supporting short-term growth, the $P$ was retained in the soils, which may improve soil fertility in the long term.
\end{abstract}

Global food production will need to double by 2050 to provide food security for 9 billion people and to meet anticipated dietary changes (Godfray et al., 2010; Tilman et al., 2011). This expansion in food production will likely double the demand for fertilizers, particularly $\mathrm{N}$ and $\mathrm{P}$ (Odegard and van der Voet, 2014). N fertilizer is primarily produced from the energy-intensive Haber-Bosch process, whereas $P$ fertilizer is now almost exclusively produced by mining phosphate rock. Fertilizer production from these processes generates large amounts of greenhouse gasses (Kool et al.,

Received for Publication 8 Feb. 2021. Accepted for Publication 18 Mar. 2021.

Published online 30 April 2021.

N.I.C. is the corresponding author. E-mail: nengiong.chan@asuedu.

This is an open access article distributed under the CC BY-NC-ND license (https://creativecommons. org/licenses/by-nc-nd/4.0/). as polyunsaturated fatty acids ( $\mathrm{Hu}$ et al., 2008) and $\beta$-carotene (García-González et al., 2005). The lipids and coproducts are extracted, leaving behind a solid residue containing important elements such as $\mathrm{N}$ and $\mathrm{P}$. In this situation, the postextraction residue can be used as a nutrient-containing soil amendment (Brennan and Owende, 2010; Hughes et al., 2013). A good example of such biofertilizers are N-fixing cyanobacteria, which have long been used in rice production (De, 1939; Venkataraman, 1981) and have been widely tested in other crops as well (Abdel-Raouf, 2012; Ibraheem, 2007; Uysal et al., 2015).

The bioavailability of the nutrients in residual algal biomass is a key issue that has been considered in previous studies. Algae have been compared with urea and inorganic fertilizers for promoting growth of a variety of food crops. Some of these studies showed no difference from inorganic fertilizers (Dadhich et al., 1969; Mulbry et al., 2005), whereas others showed that inorganic fertilizers were better (Coppens et al., 2016; Wuang et al., 2016). Comparing biomass-based fertilizers, Øvsthus et al. (2015) found that algal fertilizer was the least effective because of its high C:N ratio, and consequently, lower net $\mathrm{N}$-delivery potential. The physical status of the algal biomass also influences bioavailability. For example, applying 2 to $3 \mathrm{~g}$ of dry algae (Chlorella vulgaris) per $\mathrm{kg}$ of soil had a better effect on germination and growth of lettuce than did applying the same weight of fresh algae (Faheed and Fattah, 2008).

Recycling nutrients via microalgal biomass might be enhanced if improved crop varieties were more efficient at obtaining nutrients from recycled sources. Sustained efforts involving conventional breeding as well as genetic modifications have been under way to improve crop nutrient-use efficiency (Gaxiola et al. 2011; Veneklaas et al., 2012), the second strategy we study. An especially promising gene for improving nutrient-use efficiency is the gene coding for the type I Arabidopsis Vacuolar Pyrophosphatase, or AVP1. This gene was first isolated from vacuoles in Arabidopsis thaliana cv. Columbia and is considered a bona fide vacuolar marker (Sarafian et al., 1992), although its enzyme had been isolated much earlier (Pfankuch, 1936). Recent studies with gold-conjugated, $\mathrm{H}^{+}$-PPase-specific antibodies and proteomic approaches showed that $\mathrm{a} \mathrm{H}^{+}$PPase located in the plasma membrane was crucial in maintaining pyrophosphate homeostasis (Pizzio et al., 2015) and pyrophosphatedependent sucrose metabolism and auxin transport in the root system (Gaxiola et al., 2012; Li et al., 2005; Pizzio et al., 2015). Overexpressing the $A V P 1$ gene resulted in enhanced root growth and crop yields (Yang et al., 2007), as well as higher $\mathrm{N}$-use efficiency (Paez-Valencia et al., 2013). Although AVPl crops have been tested for nutrient uptake with conventional fertilizers, their performance with algal-based fertilizers has not been assessed.

In this study, we evaluated the suitability of dried $S$. acutus biomass as a fertilizer, in comparison with commercial fertilizer, 
for growing WT and $A V P 1$-modified lettuce (L. sativa cv. Conquistador). We tested the hypothesis that the yield of AVP1 lettuce would be higher than WT lettuce with both fertilizer types because of AVPI's ability to use assimilated nutrients more efficiently. We also tested the hypothesis that the lower availability of $\mathrm{P}$ in algal biomass, compared with commercial fertilizer, would be partially compensated by the greater ability of AVP1 lettuce to mobilize and acquire $\mathrm{P}$ from soil.

\section{Materials and Methods}

Algae, lettuce, and soil. The green alga S. acutus was mass-cultured by the Arizona Center for Algae Technology and Innovation at Arizona State University (ASU) (http:// www.azcati.com/) in standard BG-11 culture medium (Stanier et al., 1971) in $1.22 \mathrm{~m} \times$ $14.6 \mathrm{~m}$ flat-panel photobioreactors. Algal biomass was harvested by centrifugation (without extracting lipids) after 2 weeks of cultivation, freeze-dried, and crushed by a mortar and pestle. Two strains of romaine lettuce ( $L$. sativa cv. Conquistador as WT and AVP1-transformed) were the test plants. Dr. Roberto Gaxiola in the School of Life Sciences at ASU provided us with seeds of WT and AVP1-transformed lettuce. The potting soil was a mixture of Mohall sandy loam, sand, and vermiculite in 1:1:1 volume ratio with $800 \mathrm{~g}$ in each cup, that was $10 \mathrm{~cm}$ in width and $13 \mathrm{~cm}$ in length. The Mohall sandy loam came from University of Arizona Maricopa Agricultural Center. The soil is an Aridisol with bulk density of $1.65 \mathrm{~g} / \mathrm{mL}$ and its $\mathrm{pH}$ was 8.1 . Its water-holding capacity is $25.5 \%$ by volume; wilting point is $12.5 \%$; and soil texture is clay $(16.4 \%)$, sand $(72.5 \%)$, and silt $(11.0 \%)$ (Alexander et al., 1988; Lesch et al., 2005).

Greenhouse experiments. Table 1 summarizes the 20 treatments, which involved combinations of dried algae and commercial fertilizer based on the $\mathrm{N}$ addition. The treatments included a control with no additions, four algae-alone treatments (A2, A4, A6, A8, having added algal biomass equivalent to $0.2,0.4,0.6$, or $0.8 \mathrm{~g} \mathrm{~N}$ per kg dry soil), four algae $+\mathrm{P} \& \mathrm{~K}$ treatments $(\mathrm{A} 2+\mathrm{S}$, $\mathrm{A} 4+\mathrm{S}, \mathrm{A} 6+\mathrm{S}$, and $\mathrm{A} 8+\mathrm{S}$, having the same algal $\mathrm{N}$ levels plus $\mathrm{NaH}_{2} \mathrm{PO}_{4}$ at $0.33 \mathrm{~g}$ $\mathrm{P}$ per cup), and one commercial fertilizer treatment (Com, having $0.4 \mathrm{~g} \mathrm{~N}$ and $0.16 \mathrm{~g}$ $\mathrm{P}$ per kg dry soil). All algal treatments also were fertilized with $\mathrm{KOH}(390 \mathrm{mg} \mathrm{K}$ per cup) to match the $\mathrm{K}$ level in the commercial fertilizer treatment: The $\mathrm{N}-\mathrm{P}-\mathrm{K}$ nutrient proportion in the commercial fertilizer was 10-10-5 (Urea N, $\mathrm{P}_{2} \mathrm{O}_{5}, \mathrm{~K}_{2} \mathrm{O}$ ). The algae $+\mathrm{P} \& \mathrm{~K}$ treatments were enriched with inorganic $\mathrm{P}$ and $\mathrm{K}$ to ensure that all the lettuce would receive balanced nutrients close to or equivalent to the commercial fertilizer, as the algae biomass was high in N, with an $\mathrm{N}: \mathrm{P}$ ratio of $12.8: 1$ by mass.

Each treatment had 8 replicates, and we set up 160 cups: 2 (lettuce types) $\times 10$ (soil
Table 1. The masses of dried algal biomass, $\mathrm{NaH}_{2} \mathrm{PO}_{4}$, and $\mathrm{KOH}$ added to each cup in the 10 treatments: A2, A4, A6, and A8 are algal treatments; $\mathrm{A} 2+\mathrm{S}, \mathrm{A} 4+\mathrm{S}, \mathrm{A} 6+\mathrm{S}$, and $\mathrm{A} 8+\mathrm{S}$ are algal treatments with augmented $\mathrm{NaH}_{2} \mathrm{PO}_{4}$; and Com is a commercial fertilizer. Each cup contained 800 $\mathrm{g}$ of soil. All treatments (except the control) received $390 \mathrm{mg} \mathrm{KOH}$ to ensure that potassium did not become limiting in the fertilized treatments.

\begin{tabular}{lcccc}
\hline Treatment & Algae $(\mathrm{g})$ & $\mathrm{N}(\mathrm{mg})$ & $\mathrm{P}(\mathrm{mg})$ & $\mathrm{K}(\mathrm{mg})$ \\
\hline Control & 0 & 0 & 0 & 0 \\
$\mathrm{~A} 2$ & 1.56 & 200 & 15.6 & 390 \\
$\mathrm{~A} 2+\mathrm{S}$ & 1.56 & 200 & 333 & 390 \\
$\mathrm{~A} 4$ & 3.13 & 400 & 31.3 & 390 \\
$\mathrm{~A} 4+\mathrm{S}$ & 3.13 & 400 & 333 & 390 \\
$\mathrm{~A} 6$ & 4.69 & 600 & 46.9 & 390 \\
$\mathrm{~A} 6+\mathrm{S}$ & 4.69 & 600 & 333 & 390 \\
A8 & 6.25 & 800 & 62.5 & 390 \\
A8 $+\mathrm{S}$ & 6.25 & 800 & 333 & 390 \\
Com & 0 & 400 & 333 & 390 \\
\hline
\end{tabular}
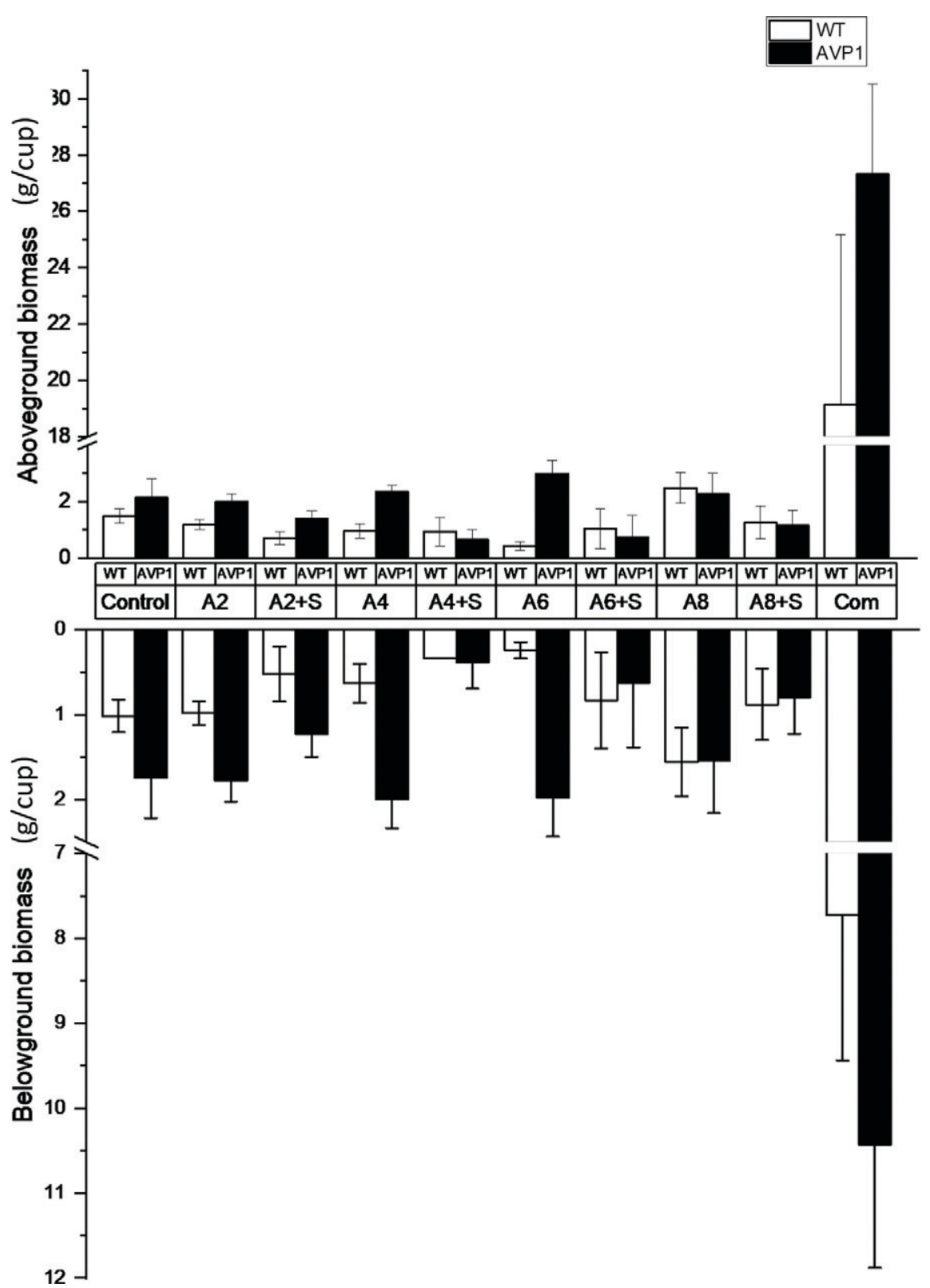

Fig. 1. Above-ground and below-ground yields of wild-type (WT) and type I Arabidopsis Vacuolar Pyrophosphatase $(A V P I)$ genetically modified Lactuca sativa cv. Conquistador for all treatments. The error bars are $95 \%$ confidence intervals. See Table 1 for details of the treatments. 
treatments $) \times 8$ (replicates). Growth experiments were conducted from $4 \mathrm{Feb}$. to 9 Mar. 2015 in a temperature-controlled greenhouse $\left(20^{\circ} \mathrm{C}\right)$ located in Tempe, AZ.

Before seed planting, dried algal biomass was mixed into the soil manually using a small spade. Soil not receiving algal biomass was mixed in the same way. Then, the soil was placed in $10-\mathrm{cm}$ plastic drinking cups with holes at the bottom for drainage. Another 10-cm cup was placed under each cup to collect leachate. Six lettuce seeds were planted in each cup. We applied Nanopure deionized water (ELGA LabWater, Woodridge, IL) for irrigation. A control treatment consisting of eight cups without any lettuce was established for leachate comparison and followed for all irrigation schedules using only Nanopure water. Commercial fertilizer and $\mathrm{NaH}_{2} \mathrm{PO}_{4}$ additions were split-added. Each cup received the same quantity of water. The first germinating seedling was selected, and other seeds were removed from the cup. The whole lettuce plant was harvested at the eight-

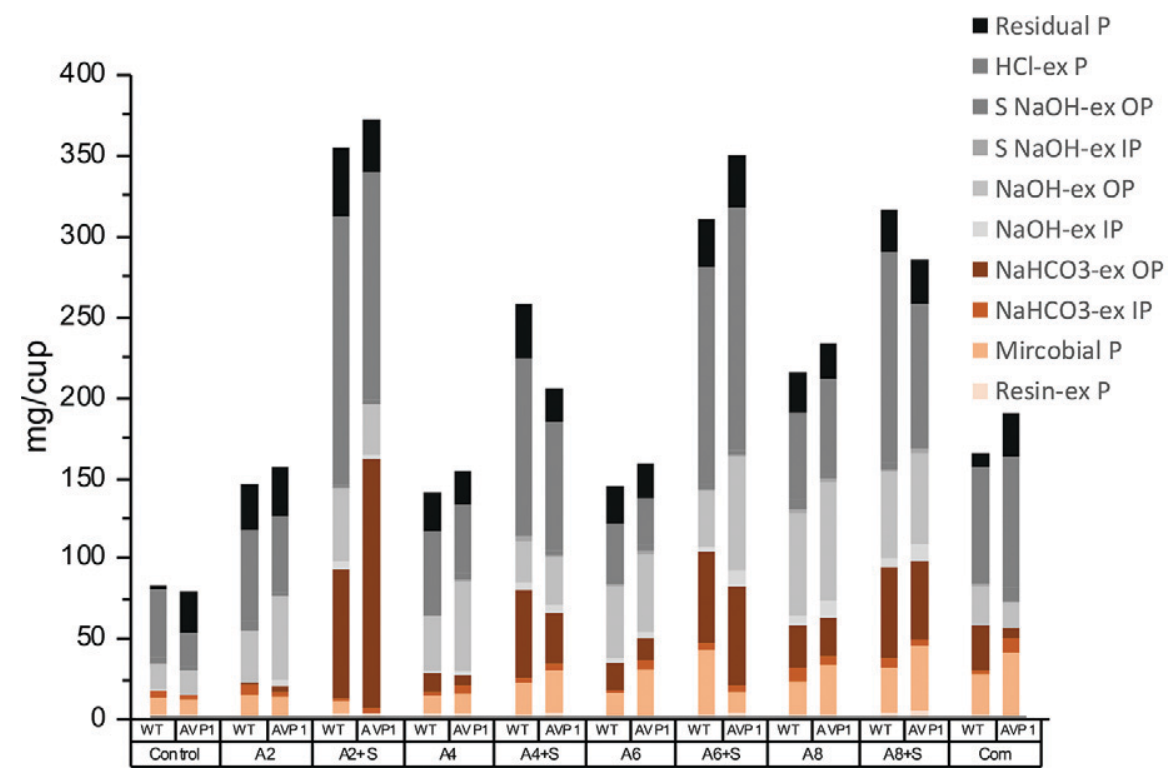

Fig. 2. Soil phosphorus (P) fractionation for all treatments. One sample was selected from each treatment for fractionation analysis. Different colors represent different $\mathrm{P}$ fractions in soil P pools; the brown and orange are the more-available pools, and with the gray/black set as the less-available pools. The Resin-ex P and S NaOH-ex Pi and Po were extremely low. Microbial P increased as the fertilization rate increased. The largest $\mathrm{P}$ pools were the $\mathrm{NaHCO}$-ex, $\mathrm{NaOH}-\mathrm{ex}$, and $\mathrm{HCl}$-ex pools. $\mathrm{NaHCO} 3-$ ex $\mathrm{Po}$ and $\mathrm{HCl}$-ex $\mathrm{P}$ were higher in algae treatments with nutrient amendments than just the algae treatments. $\mathrm{HCl}$-ex $\mathrm{Pi}=\mathrm{HCl}$-extractable inorganic $\mathrm{P}$; $\mathrm{S} \mathrm{NaOH}-\mathrm{ex} \mathrm{Pi}$ and $\mathrm{Po}=$ Sonication $\mathrm{NaOH}$-extractable inorganic and organic $\mathrm{P} ; \mathrm{NaOH}-\mathrm{ex} \mathrm{Pi}$ and $\mathrm{Po}=\mathrm{NaOH}$-extractable inorganic and organic $\mathrm{P}$; NaHCO3-ex Pi and $\mathrm{Po}=\mathrm{NaHCO} 3$-extractable inorganic and organic $\mathrm{P}$; Resin-ex $\mathrm{P}=$ Resin-extractable P.

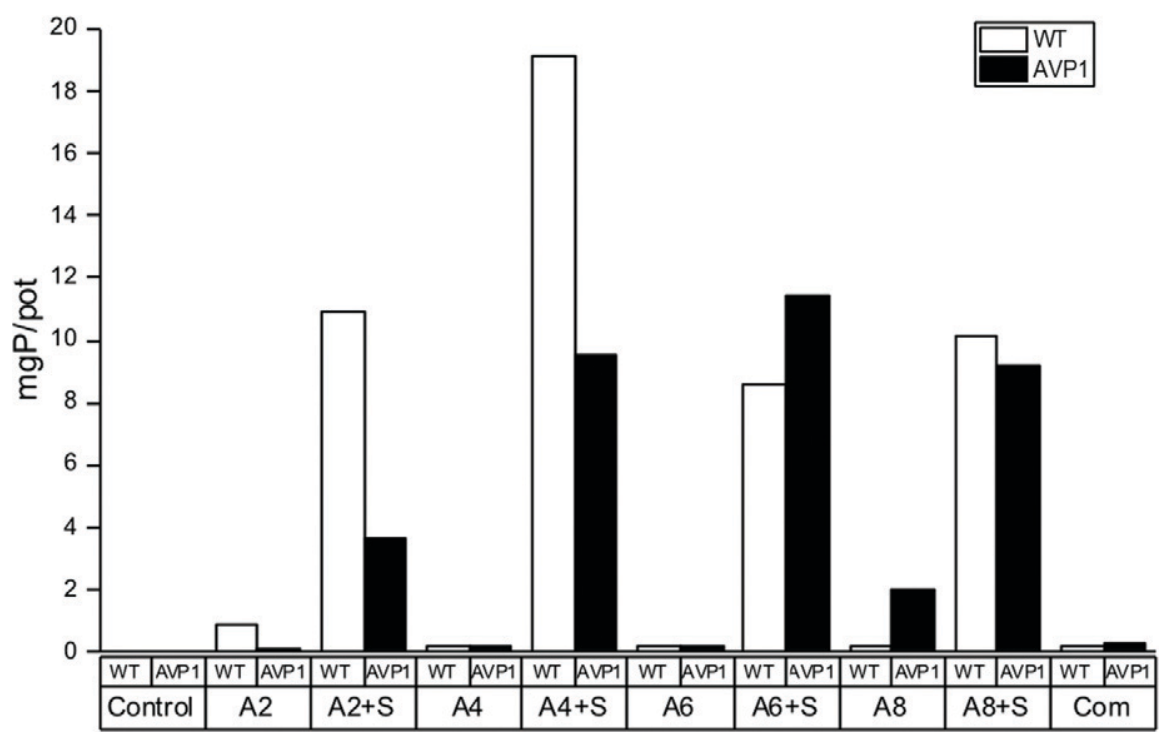

Fig. 3. Total phosphorus (P) in leachate over the growing season. Leachates in each treatment were pooled together and divided by the number of replicates.

leaf stage, which occurred after $\approx 5$ weeks. The above-ground and below-ground portions were separated, dried at $60^{\circ} \mathrm{C}$ for $48 \mathrm{~h}$, and weighed. For the below-ground samples, we washed the roots with tap water in a mesh drainer that retained fine roots that broke off.

Leachate was collected in all treatments every 2 to $4 \mathrm{~d}$ throughout the experiment. Leachate from eight replicates in a single treatment was pooled together as one sample instead of analyzing each of them separately due to the limitations of time, labor, and chemical stocks.

Soil $P$ analyses. One soil sample was selected randomly from each treatment for Pfractionation analysis. Soil $\mathrm{P}$ concentrations in 10 fractions were quantified before and after the experiment using the Hedley P-fractionation method (Hedley et al., 1982). We used Dowex 21K XLT anion-exchange resin for dissolve inorganic $\mathrm{P}$ (DIP) extraction (Gifford 2012). DIP is considered to be the most biologically available $\mathrm{P}$. $\mathrm{NaHCO}_{3}$-extractable inorganic and organic $\mathrm{P}$ are forms that are sorbed onto soil surfaces and are moderately bioavailable. $\mathrm{NaOH}$-extractable inorganic and organic $\mathrm{P}$ are held strongly by aluminum and iron components through chemisorption and are considered to be largely unavailable. $\mathrm{NaOH}-u l t r a s o n i f i c a t i o n-e x-$ tractable inorganic and organic $\mathrm{P}$ are the forms of $\mathrm{P}$ that are held at the internal surfaces of soil aggregates and are considered to be unavailable. Finally, HCl-extractable $\mathrm{P}$ mainly represents apatite-type minerals, which are not available. Soil ammonium-N and nitrate- $\mathrm{N}$ concentrations were also measured (Weaver et al., 1994), as they are soluble and mobile forms of N.

Statistical analysis. Because our data were not normally distributed, we used Tukey's Honestly Significant Difference tests to analyze the results. We used RStudio Statistic software (Mac Version 1.2.5033) and IBM SPSS Statistics software (Mac version 26.0.0.1, 64-bit edition; IBM Corp., Armonk, NY) for statistical analysis.

\section{Results and Discussion}

The biomass yields in Fig. 1 show that all treatments with dried algae gave far smaller yields than with commercial fertilizer. This trend was true for above-ground and belowground biomass. For example, the largest above-ground yield for WT lettuce in algae treatment was $2.5 \mathrm{~g} / \mathrm{cup}$ (A8), but this was only $13 \%$ of the $19 \mathrm{~g} /$ cup obtained for WT lettuce with commercial fertilizer. Algae treatments that received inorganic $\mathrm{P}$ and $\mathrm{K}$ amendments had significantly lower biomass than those without $\mathrm{P}$ and $\mathrm{K}$ amendment (above-ground biomass $P<0.0006$, belowground $P<0.004$ ).

$A V P 1$ lettuce produced higher aboveground and below-ground biomass than WT lettuce $(P<0.0001, P<0.0001)$, consistent with, but stronger than in previous studies of other plant species (Li et al., 2005; Yang et al., 2007). For example, our above-ground yield for commercial fertilizer was $27 \mathrm{~g} /$ cup for 


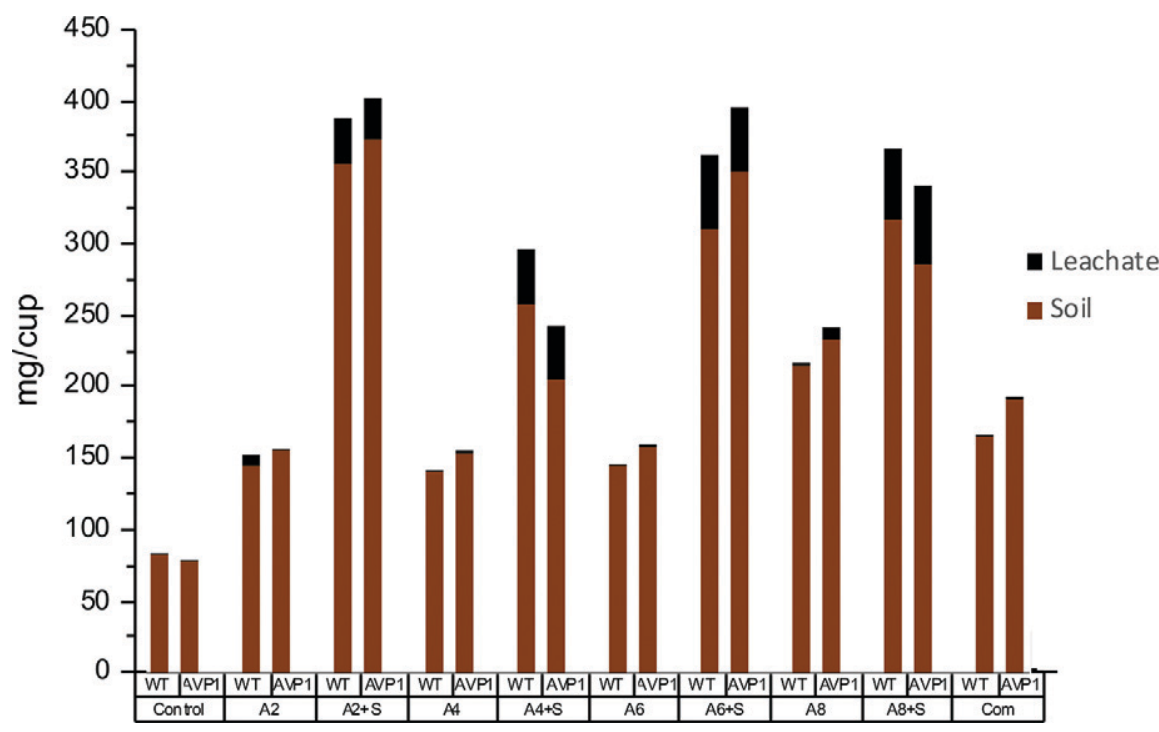

Fig. 4. Total phosphorus $(\mathrm{P})$ in soil and leachate.

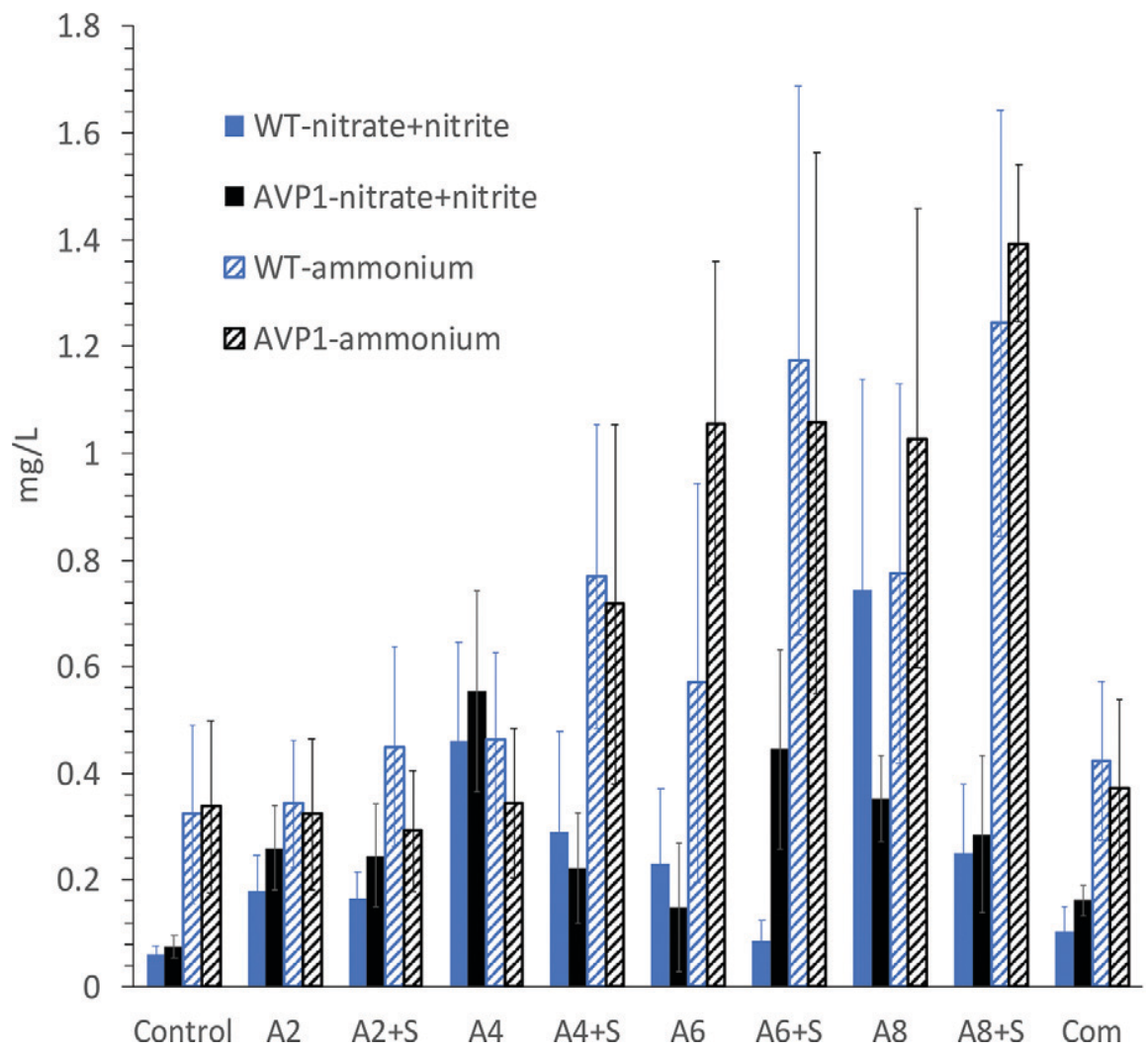

Fig. 5. Soil concentrations of nitrate + nitrite and ammonium in various treatment combinations. Although our results show that lettuce did not grow well with application of dried Scenedesmus acutus in greenhouse experiments, the soils nevertheless retained algae-derived nutrients that could become available to plants over the longer term (Garcia-Gonzalez and Sommerfeld, 2016). Thus, applying dried algae as fertilizer could benefit long-term soil nutrition, as well as improve soil organic content.

AVP1, 42\% higher than for WT. The proportional effect was even larger for the algal fertilizer, especially when supplemental $\mathrm{P}$ was not added to the algae-fertilizer treatment. In particular for A8, the above-ground yield for $A V P 1$ lettuce was more than $500 \%$ higher than for WT. For comparison, Yang et al. greater leaf area, as well as more root dry weight than the WT counterpart.

Algae treatments with $\mathrm{P}$ and $\mathrm{K}$ amendments resulted in lower biomass yields than treatments without addition of $\mathrm{P}$ and $\mathrm{K}$. We observed outer-leaf marginal necrosis on lettuce leaves from the P- and $\mathrm{K}$-amended algae biomass treatments. This potentially was due to high nutrient and salt concentrations in the amendments. For example, the amounts of $\mathrm{Na}$ added in the $\mathrm{NaH}_{2} \mathrm{PO}_{4}$ in algae treatments were less than $12 \mathrm{mg}$, but all the algae treatments with $\mathrm{P}$ and $\mathrm{K}$ amendments received $64 \mathrm{mg} \mathrm{Na}$.

The low effectiveness of the algal fertilizer may have been caused by its $P$ being unavailable for lettuce uptake. Soil $\mathrm{P}$ fractionation results in Fig. 2 show that most $\mathrm{P}$ was in the pools of $\mathrm{NaHCO}_{3}$-extractable organic $\mathrm{P}, \mathrm{NaOH}$ extractable organic $\mathrm{P}$, and $\mathrm{HCl}$-extractable $\mathrm{P}$. These forms are generally considered to be poorly available for plants (Brady and Weil, 2012; Bünemann et al., 2011; Hedley et al., 1982). Among these three less-labile $\mathrm{P}$ pools, $\mathrm{HCl}$ extractable $\mathrm{P}$ was the highest. This may have been an outcome of using $\mathrm{KOH}$ as the $\mathrm{K}$ supplement, which likely increased soil $\mathrm{pH}$. Concentrations of resin-extractable $\mathrm{P}$, the most available fractions, always were the lowest among all other available fractions. Total soil $\mathrm{P}$ was significantly higher in the algal treatments with nutrient amendments, mainly because plant growth and consequent $\mathrm{P}$ uptake were much lower with algae fertilizer compared with commercial fertilizer (Fig. 1).

Phosphorus that is not strongly complexed in soil leaches out over time. Figure 3 shows that algal treatments with nutrient amendments leached much more $P$ than treatments without fertilizer. Within the nutrient-amended algal treatments, soils supporting WT lettuce tended to lose more $\mathrm{P}$ than those supporting AVP1 lettuce, possibly due to soil acidification by the $A V P 1$ lettuce that allowed $A V P 1$ lettuce take up more P (Paez-Valencia et al., 2013; Yang et al., 2007).

Figure 4 shows total-P mass balance for the soil and leachate combined. Most of the $\mathrm{P}$ was in the soil, and leachate $P$ was significant only for algal biomass plus added nutrients. Algal treatments with nutrient amendment also had highest $\mathrm{P}$ in soil and in leachate, because the lettuce did not grow well with algal biomass plus nutrients (Fig. 1).

Figure 5, which presents the concentrations of $\mathrm{N}$ species for all treatments, makes it clear that all available $\mathrm{N}$ species were detectable in all treatments. Soil ammonium $\mathrm{N}$ and nitrate + nitrite $\mathrm{N}$ did not differ for $A V P 1$ vs. WT $(P>0.6$ and $P>0.025$, respectively). Soil ammonium $\mathrm{N}$ increased with increased algal fertilization, but remained low in the commercial fertilizer treatment. Elevated concentrations of ammonium inhibit primary root growth by causing cell death in the root meristem zone (Qin et al., 2011). The threshold of ammonium toxicity for plants is $\approx 0.04-0.4$ $\mathrm{mg} / \mathrm{L}$, depending on plant species (Britto and Kronzucker, 2002). The ammonium concentrations in our results were much higher than 
this threshold. Thus, ammonium toxicity likely was a stressor that inhibited lettuce yield and its nutrient uptake for all treatments, but especially for those with algae and added nutrients (Court et al., 1964).

In contrast to ammonium, nitrate + nitrite concentrations were higher in the algae treatments than in the commercial fertilizer treatment. Soil nitrate+nitrite was particularly high in the A4 and A8 treatments, and it was lowest in the control treatment. The commercial fertilizer treatment (Com) also had low soil nitrate + nitrite levels. These trends suggest that lettuce in commercial fertilizer treatments took up nitrogen effectively.

\section{Conclusion}

Commercial fertilizer was notably superior to dried algae in promoting yield of romaine lettuce, but AVPl-transformed lettuce had better yield than WT lettuce, particularly when supplemental $P$ was not added in algae-fertilizer treatments. The relatively poor results with algal treatments may have occurred because soil ammonium levels were inhibitory. Although the algal fertilizer was ineffective in our short-term growth experiments, the $\mathrm{P}$ was retained in the soils, which may improve soil fertility in the long term. Future studies should investigate the impacts over multiple growing seasons, as the long-term accumulation of nutrients could provide a long-term benefit.

\section{Literature Cited}

Abdel-Raouf, N. 2012. Agricultural importance of algae. Afr. J. Biotechnol. 11(54):11648-11658, doi: 10.5897/AJB11.3983.

Alexander, W.L., D.A. Bucks, and R.A. Backhaus. 1988. Irrigation water management for guar seed production. Agron. J. 80:447-453, doi: 10.2134/agronj1988.00021962008000030012x.

Brady, N.C. and R.R. Weil. 2012. Nature and properties of soils, 14th ed. Pearson, Noida, India.

Brennan, L. and P. Owende. 2010. Biofuels from microalgae-A review of technologies for production, processing, and extractions of biofuels and co-products. Renew. Sustain. Energy Rev. 14(2):557-577, doi: 10.1016/j.rser.2009.10.009.

Britto, D.T. and H.J. Kronzucker. 2002. NH4+ toxicity in higher plants: A critical review. J. Plant Physiol. 159:567-584, doi: 10.1078/01761617-0774.

Bünemann, E.K., A. Oberson, and E. Frossard. 2011. Soil biology: Phosphorus in action. Biological Processes in Soil Phosphorus Cycling. Springer, New York.

Carriquiry, M.A., X. Du, and G.R. Timilsina. 2010. Second-generation biofuels economics and policies. Policy Research Working Paper 5406, The World Bank, Development Research Group, Environment and Energy Team, (August), 55 .

Coppens, J., O. Grunert, S. Van Den Hende, I. Vanhoutte, N. Boon, G. Haesaert, and L. De Gelder. 2016. The use of microalgae as a highvalue organic slow-release fertilizer results in tomatoes with increased carotenoid and sugar levels. J. Appl. Phycol. 28(4):2367-2377, doi: 10.1007/s10811-015-0775-2.

Court, M.N., R.C. Stephen, and J.S. Waid. 1964. Toxicity as a cause of the inefficiency of urea as a fertilizer. I. Review. J. Soil Sci. 15(1):42-48, doi: 10.1111/j.1365-2389.1964.tb00243.x.

Dadhich, K.S., A.K. Varma, and G.S. Venkataraman. 1969. The effect of calothrix inoculation on vegetable crops. Plant and Soil 31(2):377-379, doi: 10.1007/BF01373582

De, P.K. 1939. The role of blue-green algae in nitrogen fixation in rice-fields. Proc. R. Soc. Lond. B Biol. Sci. 127(846):121-139, doi: 10.1098/rspb.1939.0014.

Faheed, F.A. and Z.A.E. Fattah. 2008. Effect of chlorella vulgaris as bio-fertilizer on growth parameters and metabolic aspects of lettuce plant. J. Agr. Social Sci. 4(1965):165-169.

Ferber, D. 2004. Dead zone fix not a dead issue. Science 305(5690):1557, doi: 10.1126/science. 305.5690.1557.

Garcia-Gonzalez, J. and M. Sommerfeld. 2016. Biofertilizer and biostimulant properties of the microalga Acutodesmus acutus. J. Appl. Phycol. 28(2):1051-1061, doi: 10.1007/s10811-0150625-2.

García-González, M., J. Moreno, J.C. Manzano, F.J. Florencio, and M.G. Guerrero. 2005. Production of Dunaliella salina biomass rich in 9cis- $\beta$-carotene and lutein in a closed tubular photobioreactor. J. Biotechnol. 115(1):81-90, doi: 10.1016/j.jbiotec.2004.07.010.

Gaxiola, R.A., M. Edwards, and J.J. Elser. 2011. A transgenic approach to enhance phosphorus use efficiency in crops as part of a comprehensive strategy for sustainable agriculture. Chemosphere 84:840-845, doi: 10.1016/j.chemosphere. 2011.01.062.

Gaxiola, R.A., C.A. Sanchez, J. Paez-Valencia, B.G. Ayre, and J.J. Elser. 2012. Genetic manipulation of a "vacuolar" H+-PPase: From salt tolerance to yield enhancement under phosphorus-deficient soils. Plant Physiol. 159:3-11, doi: 10.1104/pp.112.195701.

Gifford, J.M. 2012. Phosphorus recovery from microbial biofuel residual using microwave peroxide digestion and anion exchange. Arizona State University, Tempe, Master's thesis.

Godfray, H.C.J., J.R. Beddington, I.R. Crute, L. Haddad, D. Lawrencce, J.F. Muir, J. Pretty, S. Robinson, S.M. Thomas, and C. Toulmin. 2010. Food security: The challenge of feeding 9 billion people. Science 327:812-818, doi: 10.1126/science. 1185383 .

Hedley, M.J., J.W.B. Stewart, and B.S. Chauhan. 1982. Changes in inorganic and organic soil phosphorus fractions induced by cultivation practices and by laboratory incubations. Soil Sci. Soc. Amer. J. 46:970-976, doi: 10.2136/ sssaj1982.03615995004600050017x.

Hu, C., M. Li, J. Li, Q. Zhu, and Z. Liu. 2008. Variation of lipid and fatty acid compositions of the marine microalga Pavlova viridis (Prymnesiophyceae) under laboratory and outdoor culture conditions. World J. Microbiol. Biotechnol. 24(7):1209-1214, doi: 10.1007/ s11274-007-9595-0.

Hughes, S.R., W.R. Gibbons, B.R. Moser, and J.O. Rich. 2013. Sustainable multipurpose biorefineries for third-generation biofuels and value-added co-products. Biofuels Economy, Environment and Sustainability 2013:245-262, doi: 10.5772/62530.

Ibraheem, I.B.M. 2007. Cyanobacteria as alternative biological conditioners for bioremediation of barren soil. Egyption J. Phycology 8:99-117, doi: 10.21608/EGYJS.2007.114548.

Kool, A., M. Marinussen and H. Blonk. 2012. LCI data for the calculation tool Feedprint for greenhouse gas emissions of feed production and utilization, GHG emissions of N, P and $\mathrm{K}$ fertilizer production, 34. Blonk
Consultants, PJ Gouda, Netherlands, p. 2805, Gravin Beatrixstraat.

Lesch, S.M., D.L. Corwin, and D.A. Robinson. 2005. Apparent soil electrical conductivity mapping as an agricultural management tool in arid zone soils. Comput. Electron. Agr. 46: 351-378, doi: 10.1016/j.compag.2004.11.007.

Li, J., H. Yang, W.A. Peer, G. Richter, J. Blakeslee, A. Bandyopadhyay, B. Titapiwantakun, S. Undurraga, M. Khodakovskaya, E.L. Richards, B. Krizek, A.S. Murphy, S. Gilroy, and R. Gaxiola. 2005. Arabidopsis $\mathrm{H}+-\mathrm{PPase} A V P 1$ regulates auxin-mediated organ development. Science 310:121-125, doi: 10.1126/science.1115711.

Li, W.W., H. Yu, and B.E. Rittmann. 2015. Reuse water pollutants. Nature 528:29-31, doi: $10.1038 / 528029 \mathrm{a}$

Mikkelsen, R. 2011. The "4R" nutrient stewardship framework for horticulture. HortTechnology 21(6):658-662, doi: 10.21273/ HORTTECH.21.6.658.

Mulbry, W., E.K. Westhead, C. Pizarro, and L. Sikora. 2005. Recycling of manure nutrients: Use of algal biomass from dairy manure treatment as a slow release fertilizer. Bioresour. Technol. 96(4):451-458, doi: 10.1016/ j.biortech.2004.05.026.

Odegard, I.Y.R. and E. van der Voet. 2014. The future of food-Scenarios and the effect on natural resource use in agriculture in 2050. Ecol. Econ. 97:51-59, doi: 10.1016/j.ecolecon.2013.10.005.

Øvsthus, I., T.A. Breland, S.F. Hagen, K. Brandt, A.B. Wold, G.B. Bengtsson, and R. Seljåsen. 2015. Effects of organic and waste-derived fertilizers on yield, nitrogen and glucosinolate contents, and sensory quality of broccoli (Brassica oleracea L. var. italica). J. Agr. Food Chem. 63 (50):10757-10767, doi: 10.1021/acs.jafc.5b04631.

Paez-Valencia, J., J. Sanchez-Lares, E. Marsh, L.T. Dorneles, M.P. Santos, D. Sanchez, A. Winter, S. Murphy, J. Cox, M. Trzaska, J. Metler, A. Kozic, A.R. Facanha, D. Schachtman, C.A. Sanchez, and R.A. Gaxiola. 2013. Enhanced proton translocating pyrophosphatase activity improves nitrogen use efficiency in romaine lettuce. Plant Physiol. 161:1557-1569, doi: 10.1104/pp.112.212852.

Pfankuch, E. 1936. Über die phosphatase der kartoffel und der yuckerrübe. Hoppe Seylers Z. Physiol. Chem. 241:34-36.

Pizzio, G.A., J. Paez-Valencia, A.S. Khadilkar, K.C. Regmi, A. Patron-Soberano, S. Zhang, J. Sanchez-Lares, T. Furstenau, J. Li, C. SanchezGomez, P. Valencia-Mayoral, U.P. Yadav, B.G. Ayre and R.A. Gaxiola. 2015. Arabidopsis proton-pumping pyrophosphatase AVP1 expresses strongly in phloem where it is required for PPi metabolism and photosynthate partitioning. Plant Physiol. 167:114.254342, doi: 10.1104/pp.114.254342.

Qin, C., K. Yi and P. Wu. 2011. Ammonium affects cell viability to inhibit root growth in Arabidopsis. J. Zhejiang University-SCIENCE B (Biomedicine \& Biotechnology) 12(6):477-484, doi: 10.1126/science.279.5349.407.

Rittmann, B. and P. McCarty. 2020. Environmental biotechnology: Principles and applications. 2nd ed. McGraw Hill, New York.

Sarafian, V., Y. Kim, R.J. Poole, and P.A. Rea 1992. Molecular cloning and sequence of cDNA encoding the pyrophosphate-energized vacuolar membrane proton pump of Arabidopsis thaliana. Proc. Natl. Acad. Sci. USA 89: 1775-1779, doi: 10.1073/pnas.89.5.1775.

Smith, V. and D. Schindler. 2009. Eutrophication science: Where do we go from here? Trends Ecol. Evol. 24(4):201-207, doi: 10.1016 j.tree.2008.11.009 
Stanier, R.Y., R. Kunisawa, M. Mandel, and G. Cohen-Bazire. 1971. Purification and properties of unicellular blue-green algae (Order Chroococcales). Bacteriol. Rev. 35(2):171-205, doi: 10.1016/j.jbiotec.2013.07.020.

Tilman, D., C. Balzer, J. Hill, and B.L. Befort. 2011. Global food demand and the sustainable intensification of agriculture. Proc. Natl. Acad. Sci. USA 108(50):20260-20264, doi: 10.1073/ pnas. 1116437108 .

Uysal, O., F.O. Uysal, and K. Ekinci. 2015. Evaluation of microalgae as microbial fertilizer. Eur. J. Sustain. Dev. 4(2):77-82, doi: 10.14207/ ejsd.2015.v4n2p77.
Veneklaas, E.J., H. Lambers, J. Bragg, P.M. Finnegan, C.E. Lovelock, W.C. Plaxton, C.A. Price, W. Scheible, M.W. Shane, P.J. White, and J.A. Raven. 2012. Opportunities for improving phosphorus-use efficiency in crop plants. New Phytol. 195(2):306-320, doi: 10.1111/j.1469-8137.2012.04190.x.

Venkataraman, G.S. 1981. Blue-green algae: A possible remedy to nitrogen scarcity. Curr. Sci. 50(6):253-256.

Weaver, R.W., S. Angle, P. Bottomley, D. Bezdicek, S. Smith, A. Tabatabai, and A. Wollum. 1994. Methods of soil analysis. Part 2, Microbiological and biochemical properties. Soil Science Society of America Book Series, Inc., Madison, WI.

Wuang, S.C., M.C. Khin, P.Q.D. Chua, and Y.D. Luo. 2016. Use of Spirulina biomass produced from treatment of aquaculture wastewater as agricultural fertilizers. Algal Res. 15(April):59-64, doi: 10.1016/j.algal.2016.02.009.

Yang, H., J. Knapp, P. Koirala, D. Rajagopal, W.A. Peer, L.K. Silbart, A. Murphy, and R.A. Gaxiola. 2007. Enhanced phosphorus nutrition in monocots and dicots over-expressing a phosphorus-responsive type I $\mathrm{H}+$-pyrophosphatase. Plant Biotechnol. J. 5(6):735-745, doi: 10.1111/ j.1467-7652.2007.00281.x. 